\title{
WHEN THE MUSIC ENDS
}

\section{Criminal records.}

\section{BY PHILIP BALL}

$\mathrm{I}_{\mathrm{H}}^{\mathrm{n}}$ listened to Henry Purcell's When I am Laid in Earth this morning, although I know it is a crime. When I cried, it wasn't because I felt ashamed. They were joyous tears; I was undone by beauty.

But that's not why I'm crying now, hammer in hand, shards of black shellac at my feet. It's possible that no one now will hear Dido's lament ever again. I can't bear that thought, but what choice did I have? Now I see why music was so dangerous.

Let me explain: yes, I can hear music. We do exist, the rumours are true. There are all kinds of reasons why some people evade the embryo screening, but I guess my parents' motivations were the usual sort: a quirk of their genetic combination made it impossible to conceive a healthy child, to pass on their congenital amusia, and they couldn't afford the cost or risk of the precarious gene therapies we have now. It's cheaper, in the end, to bribe the doctor.

Of course, many of us musics never even discover our condition, not really. Perhaps we feel a weird thrill at the song of a nightingale, even at the shallow prosody that, in spite of ourselves, speech still retains. But I have real music to listen to.

You see, my great-grandfather ran a museum of music technology, and his collection of long-playing records survived the digital purge, that mass wiping of melodious data. He knew it was dangerous but he couldn't help himself, he kept all these discs and an old hand-wound gramophone in this remote retreat in the hills. That's where I've spent the past month and more, cranking my way through Albeníz, Albert Ammons, Aerosmith - names whispered fearfully now, like a catalogue of medieval demons. It was when I got to Bach that I began fully to understand how perilous this stuff was. Yet only Purcell has tipped me into destruction. I feel I have betrayed my ancestors, but it's either that or betray your children.

My great-grandfather's diaries give a truer picture than the official accounts. The problem, I now see, was when we found a way to explore musical space automatically. If it hadn't been for music-generating algorithms, we'd have probably languished indefinitely in this harmless territory all around me, where music could do nothing

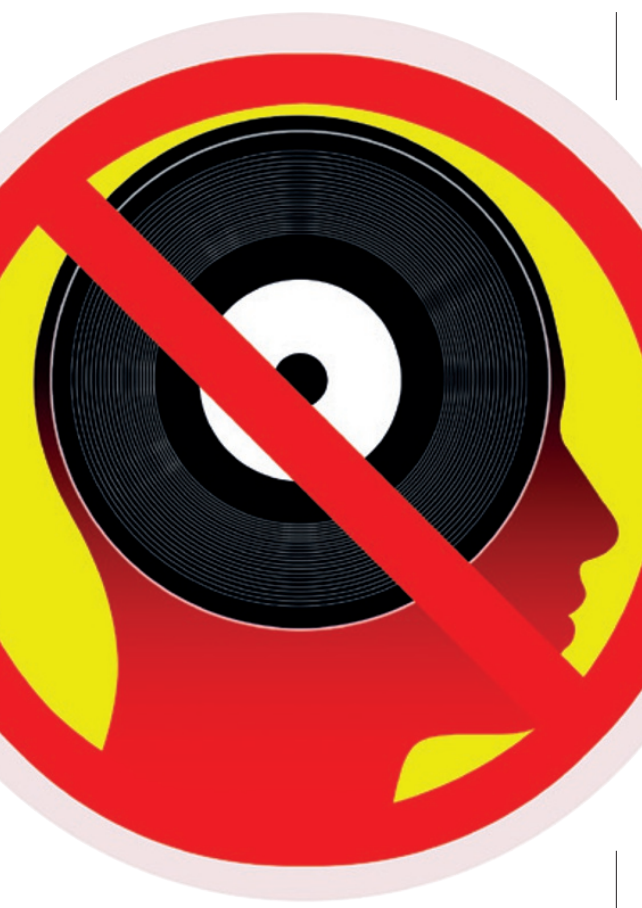

worse than make us weep, or laugh, or dance or recover the will to live.

Of course, no one meant to develop such a lethal strain of music, even the approved histories will admit that. Those researchers had no idea that such a fatal realm of musical space existed. But once they put emotionality into the fitness functions of their genetic algorithms, it was inevitable that the computer's compositions would start drifting towards that place. The commercial systems were crude explorers: users, craving the exquisite and blissful pang, could and did turn up the setting to full while only ever encroaching on the borders of the dangerous terrain. No, it was in the laboratory that the advanced tools existed to carry the quest across the boundary.

I now see that those explorers were not, as we have been told, reckless fools. They couldn't have known or even suspected what lay in wait, their benign intentions untrammelled by a knowledge of music's devastating seductions. The better it got, the more vindicated they felt. There were no containment procedures - why should there have been? Such a short step, in the end, $\rightarrow$ NATURE.COM and colleagues "You FollowFutures: must hear this" to @NatureFutures the glassy-eyed f go.nature.com/mtoodm stupor that became the symptom of imminent succumbing. And who could ever have contained that digital virus, spreading through our invisible networks in just a few terrible weeks,

depriving everyone beyond the age of infant-learned receptivity of their will to work, to eat, to remove their headphones even in the face of their deepest instincts for survival and progeniture? Like all viruses, it adapted itself to the local circumstances: the deadly trance was soon induced by hyper-emotive gamelan, hymn, tribal chant, generated in inexhaustible supply. The economy collapsed and people starved, for in the end music is not a food of any sort.

Only the total amusics survived, and only those whose condition was congenital could hope to breed. Darwin would have understood, for he would have been among the survivors.

Real dangers always beget taboos and then laws. Those decades after the disintegration saw such hardship and horror that it's no wonder amusia is now a legal condition of carrying a fetus, even while it is a crime to possess instruments or recordings one cannot use to any effect. But still we have emerged again, knowing we must keep our condition hidden. And even if the digital world is rigorously monitored for anything that might be considered musical (to the extent that amusics can judge), it has never been possible to eliminate all vestiges of humanity's past passions.

When I discovered this hoard, at first its contents made little auditory sense. But we are still pattern-seekers, and it didn't take me long to hear, and finally to adore, music's cognitive games. Every disc is a revelation: Couperin, Abbey Road, Judy Garland's Over the Rainbow. I think of Bach sent floating in golden grooves a century ago towards other stars, and wonder: have we polluted the cosmos, or after all enriched it?

But that Purcell. Finally, I saw beyond this rapture to something of such overwhelming beauty that I needed, in my fear, to shatter it. Now I stand here grasping the weapon, all these glittering black discs laid out before me.

Philip Ball is an author. His latest book is Invisible: The Dangerous Allure of the Unseen (Bodley Head). 